XIV Российская национальная конференция по сейсмостойкому строительству и сейсмическому районированию (с международным участием). Сборник материалов

УДК 624.012:691.714:624.014

DOI 10.37153/2687-0045-2021-14-118-120

\title{
ИССЛЕДОВАНИЯ ПРОЧНОСТИ И ДЕФОРМАЦИЙ ЖЕЛЕЗОБЕТОННЫХ БАЛОК ПОСЛЕ ДОСТИЖЕНИЯ ПРЕДЕЛА ТЕКУЧЕСТИ В АРМАТУРЕ
}

\section{STUDIES OF THE STRENGTH AND DEFORMATIONS OF REINFORCED CONCRETE BEAMS AFTER REACHING THE YIELD STRENGTH IN THE REINFORCEMENT}

Тихонов Г.И., инженер-конструктор Отдела инновационных разработок и конструктивных решений проектно-конструкторского Центра № 25 НИИЖБ им. А.А. Гвоздева АО «НИЦ «Строительство»

Tikhonov G.I., design Engineer of the Department of Innovative Developments and design Solutions of the Design Center № 25 of NIIZhB n.a. A.A. Gvozdev JSC "SIC"Construction"

Аннотация: Выполнены исследования образцов-балок с винтовой четырехрядной арматурой класса Ав500П и Ав600П и бетоном классов В30 и В60 при статическом нагружении при изгибе в эксплуатационной стадии и после достижения предела текучести в арматуре.

Результаты исследований показали высокую эффективность применения новой винтовой арматуры, в том числе с муфтовыми соединениями, для выполнения требований действующих норм по прочности, жесткости и трещиностойкости.

Они также показали, что для обеспечения эксплуатационной надежности железобетонных конструкций за счет пластического деформирования их расчетных сечений, в том числе при аварийных динамических и сейсмических нагружениях, следует при проектировании использовать различные приемы конструирования для снижения относительной высоты сжатой зоны бетона сечений этих элементов, например за счет изменения их высоты и геометрической формы (использование приопорных вутов для балок, Т- и П-образных сечений для балок и пилонов колонн, капителей колонн для безбалочных перекрытий и др.).

Abstract: Studies of samples-beams with four-row screw reinforcement of class Av500P and Av600P and concrete of classes B30 and B60 under static loading during bending in the operational stage and after reaching the yield strength in the reinforcement were performed.

The research results have shown the high efficiency of using new screw fittings, including those with coupling connections, to meet the requirements of the current standards for strength, stiffness and crack resistance.

They also showed that in order to ensure the operational reliability of reinforced concrete structures due to plastic deformation of their design cross-sections, including during emergency dynamic and seismic loads, various design techniques should be used in the design to reduce the relative height of the compressed concrete zone of the cross-sections of these elements, for example, by changing their height and geometric shape (using support screws for beams, $\mathrm{T}$ and U-shaped sections for beams and column pylons, column capitals for girderless floors, etc.).

Ключевые слова: железобетон, арматура, изгибаемые конструкции, балочный элемент, винтовой профиль

Keywords: reinforced concrete, reinforcement, bendable structures, beam element, screw profile 
XIV Российская национальная конференция по сейсмостойкому строительству и сейсмическому районированию (с международным участием). Сборник материалов

Арматура с четырехсторонним (четырехрядным) винтовым профилем классов Ав500П и Ав600П благодаря высокому критерию Рема, улучшенному сцеплению с бетоном и уменьшению ширины раскрытия трещин, а также инновационному винтовому профилю представляет собой перспективный объект для научных исследований и последующего внедрения в практику проектирования и строительства.

Для исследования прочности и деформаций изгибаемых конструкций, армированных арматурой классов Ав500П и Ав600П, была проведена серия экспериментов на армированных балочных элементах.

Задачами проведенных испытаний являлись:

- исследование прочности, жесткости и трещиностойкости изгибаемых балочных элементов, армированных винтовой арматурой классов Ав500П и Ав600П;

- исследование влияния стыкового муфтового соединения на прочность, жесткость и трещиностойкость изгибаемых элементов;

- исследования деформативности и трещиностойкости изгибаемых балочных железобетонных элементов с арматурой класса Ав500П и Ав600П одинаковой прочности, но с разной высотой и армированием сечений, в эксплуатационной и запредельной стадии (после достижения предела текучести в арматуре $\left.\sigma_{m(0,2)}\right)$ нагружения.

Для проведения испытаний было изготовлено 20 балок: двенадцать размером 120x200x1800 мм и восемь размером 120х300x1800 мм.

Армирование и высота сечения балок подбирались из условия обеспечения их равнопрочности: балки высотой 200 мм армировались в растянутой зоне двумя стержнями диаметром 16 мм классов Ав500П и Ав600П, а балки высотой 300 мм - двумя стержнями диаметром 12 мм классов Ав500П и Ав600П.

В рамках эксперимента в части образцов стержни были разделены на две части и соединены нарезными муфтами.

Так как предполагалось тщательное исследование характера пластического деформирования балок в запредельной стадии, что обеспечивалось минимальными значениями относительной высоты сжатой зоны, армирования сжатой зоны балок не предусматривалось во избежание его влияния на прочностные и деформационные свойства бетона. Для исключения разрушения балок по наклонному сечению предусматривалось усиленное армирование их приопорных зон поперечными замкнутыми хомутами.

Образцы изготавливались из бетонов классов В30 и В60 составов завода ЖБИ, на котором были изготовлены балки. Испытания выполнялись на универсальной испытательной машине Instron 8802250 кН.

В процессе испытаний определялись прогибы балок с учетом осадки опор, деформации бетона при сжатии и растяжении, совместные деформации бетона и арматуры при растяжении с использованием индикаторов часового типа и прогибомеров, также визуально (при помощи микроскопа) определялась ширина раскрытия трещин.

Образцы-балки загружались ступенями, не превышающими 10\% от разрушающей нагрузки $P_{\text {test }}$, до уровня, равного $0,8 P_{\text {test }}$. После этого ступени уменьшали до $5 \% P_{\text {test }}$ до достижения напряжений в арматуре предела текучести. Дальнейшее нагружение производилось ступенями по 100 кгс до разрушения балок. Это позволило оценить поведение балок при их деформировании в пластической стадии, вплоть до их разрушения, и стало возможным из-за особенностей деформирования современных видов термомеханически упрочненного арматурного проката класса прочности А500 и А600, имеющего в первом случае небольшую площадку текучести (менее 1\%) и во втором случае -ее отсутствие. После каждой ступени приложения нагрузки делалось $5 \div 10$ мин выдержка под нагрузкой с замерами показаний приборов до и после выдержки. 
XIV Российская национальная конференция по сейсмостойкому строительству и сейсмическому районированию (с международным участием). Сборник материалов

\section{Заключение}

Проведенные исследования показали эффективность применения винтовой арматуры классов Ав500П и Ав600П в изгибаемых элементах, изготовленных из бетонов классов В30 и В60, для выполнения требований действующих нормативных документов по прочности, жесткости и трещиностойкости.

Полученные из опыта показатели по деформативности, трещинообразованию и ширине раскрытия трещин предполагают возможность корректировки расчетных формул действующих норм для арматуры с винтовым четырехрядным профилем в сторону уменьшения значений, что позволит обеспечить повышенные технико-экономические показатели проектирования объектов строительства.

Проведенные исследования показали, что для обеспечения эксплуатационной надежности железобетонных конструкций за счет пластического деформирования их расчетных сечений, в том числе при аварийных динамических нагружениях, следует при проектировании использовать различные приемы конструирования для снижения относительной высоты сжатой зоны бетона сечений этих элементов, например за счет изменения их высоты и геометрической формы (использование приопорных вутов для балок, Т- и П-образных сечений для балок и пилонов колонн, капителей колонн для безбалочных перекрытий и др.).

Примененные в опытах муфтовые соединения арматуры диаметром 16 мм классов Ав500П и Ав600П с затяжкой контргаек усилием $350 \mathrm{H} \cdot \mathrm{M}$ показали возможность их применения без каких-либо изменений действующих норм в части расчетной методики. 